\title{
The Teaching Reform under the Applied Transformation by Case Teaching Method
}

\author{
Mei Chiao Lai \\ Fuzhou University of International Studies and Trade \\ Fuzhou, Fujian, 350202
}

\author{
Chien Jen Hung \\ Fuzhou University of International Studies and Trade \\ Fuzhou, Fujian, 350202
}

\begin{abstract}
The applied transformation of colleges and universities is purposed to cultivate the talents for local industry. Taking the logistics marketing teaching as an example and in combination with the real cases of enterprises, this article is designed to make students familiar with theories and concepts through the knowledge manifested in the cases, master management skills and eventually achieve the conversion of behaviors even beliefs as well as the seamless connection between theory and practice through the study of cases. This paper introduces the case teaching from three parts: teaching plan, case text and teaching guideline. The results figure out that a successful case teaching should be emphasized on three elements, in terms of the teaching ability of teachers, the study and practice ability of students and the design of practical curriculum materials.
\end{abstract}

Keywords — applied transformation; logistics marketing; case teaching

\section{INTRODUCTION-RESEARCH MOTIVATION AND PURPOSE}

In order to fully facilitate the development of modern vocational educational policies, the State Council issues the Decisions on Accelerating Development of Modern Vocational Education and puts forward "to build a worldclass modern vocational education system with Chinese characteristics by 2020 , which will achieve the goals of meeting the development demand, deep integration of production and teaching, linkage between secondary vocational education and higher vocational education, mutual communications between vocational education and general education, realization a life-long educational philosophy". Meanwhile, the Guidelines on the Transformation of Local Undergraduate Universities to Applied Ones with YJF[2015] Fine No.7 points out that the education in universities should establish applied personnel training model and realize the connection between specialty and industry, between course content and occupational standard, and between teaching process and production process. The national policy requires connecting teaching process of universities with the production process, which is the first research motivation.
Gao Xu

Fuzhou University of International Studies and Trade Fuzhou, Fujian, 350202

In March 2014, the reform direction of the Ministry of Education of the People's Republic of China was to gradually transform more than 600 of 1200 colleges and universities into applied technique-oriented colleges and universities. The transformed undergraduate colleges and universities exactly accounted for $50 \%$ of the total colleges and universities. The applied transformed undergraduate colleges and universities should cultivate high-level applied talents so as to meet the demands of industries, which is the second research motivation.

Reviewing the historical conditions for the development of China's industries, all enterprises in cases have time and space background and biographies of their own. Through the presentation of complete historical background, it can more completely show the environmental opportunity and restriction of Chinese enterprises in the making of a series of decisions. Therefore, the cases have longitudinal temporal elements, namely, they should present the management behaviors of operators based on decades of sustainable development of an industry or an enterprise. Whether the logistics marketing should adopt the case teaching method in the class teaching to successfully integrate with the industry is the third research motivation.

The logistics marketing is to study the theories, operation rules and management of all fields relevant to logistics activities, which has strong applicability and has the characteristics of closely linking theory with practice. Whether it can adopt the case teaching to meet practices and to serve the logistics construction of local industry is the fourth research motivation.

Based on the above motivations, the research purposes of this paper are presented as follows:

- To explore the significance and characteristics of case teaching in the logistics marketing teaching;

- To discuss the feasibility of class case teaching in the logistics marketing teaching under the background of applied transformation; 
- To enumerate the programs of class case teaching of logistics marketing to serve the practice.

\section{LITERATURE REVIEW}

In the modern society, talents can be classified from different perspectives. According to the purpose of production or work, the talents can be divided into four types as academic (theoretical), engineering, technical and skilled. The talents training objective of logistics marketing is to cultivate special talents who have manager potential in accordance with the national guiding principle for education. Therefore, the teaching methods and textbook contents of logistics marketing in undergraduate institutions should conform to the industrial demands, which have become an important topic for discussion.

\section{A. Training of Applied Talents}

The so-called applied talent refers to a special talent type that can apply professional knowledge and skills to the social practices related to the major. According to the International Standard Classification of Education (ISCED) issued by the United Nations Educational, Scientific and Cultural Organization (UNESCO) in 1997, the general higher education should cultivate academic and engineering talents while the higher vocational education should train applied talents of advanced technologies. The technical or professional talents should skillfully master the basic knowledge and skills for the forefront of social production or activities, who will be mainly engaged in the forefront of production. With the development of higher education, the specific connotation for applied talents continually develops.

The 2014 annual key work point of the Ministry of Education pointed out that it need to strengthen the cultivation of applied talents, guide the transformation of undergraduate institutions to applied technical colleges and universities driven by pilot units and led by demonstrative units, and lead the transformation of a batch of undergraduate institutions to applied technical colleges and universities and focus on the undergraduate vocational education. When independent colleges are transformed to independently set up higher education institutions, they should be encouraged to make orientation of applied technical institutions.

\section{B. Case Teaching}

The case teaching method refers to the interactive teaching method that teachers apply practical cases and enlighten independent thought and collective collaboration of students in accordance with teaching objective and contents staged in the teaching syllabus, make groups or individuals conduct discussion or analysis on the information and problems provided by cases and further put forward their own views and make judgment and decisions under the guidance of teachers, so as to improve their abilities of analyzing and solving problems. The case teaching method is a participant-centered learning method. Both teaching and learning are a valuable experience. Students should actively seek and answer problems; the responsibilities of teachers are to guide students to seek problems and the methods and skills of answers. In the class, students are protagonists; teachers are promoters, coordinators or conductors; and teachers also can play roles to interact with students. Moreover, the design of classroom should make students see each other easily for the interaction and mutual learning. The class teaching is similar to a play. The teacher plays the role of director to guide students to try their best to performance in accordance with the script (teaching plan). If the director properly commands, students can acquire knowledge of the subject, understand the logic process and build the reasoning ability; teachers and students can gain exciting experience during the performance. Therefore, students can comprehend the knowledge and get knowledge in a long-term memory. When the teacher changes between different roles, they can adopt such methods as difference of tones, change of countenance and attitudes, choice of specific position in the classroom (front/rear stage).

The expected effect of the case teaching can be evaluated from three levels, namely, knowledge, skill and attitude. On the knowledge, the students are familiar with the cases familiar with theories and concepts; on the skill, the students are familiar with the cases $\rightarrow$ familiar with the management skills; on the attitude, the students are familiar with the cases change of behaviors and belief. The advantage of the case teaching is that it can develop the interest of students, for the individual case teaching is much more interesting than the traditional teaching; teachers can learn while teaching students, because students always bring unexpected pleasant surprises for teachers; the case teaching is a diversified learning style, because the classroom discussion can motivate multi-directional thinking and creativity, cultivate practical talents, and cultivate knowledge, skill and attitude of students in the practice.

The case type can be divided into two types, namely, teaching-oriented individual cases and theoretical individual cases. The theoretical individual cases lay equal emphasis on the topic of decisions for discussion and the theory and model discussed. For example, the issue discussed in the case may be whether and how an enterprise gets itself to the international market, and the author may choose to discuss the theory and viewpoint. In the case, we should correctly discuss the correlation between issue and theoretical model, and effectively apply the theoretical model to solve the problems in the case. The main purpose of theoretical cases is to directly put the theory or model of management field into the case and impart the theory or model to students in the teaching process. As to the theoretical analysis results of theoretical cases, the teachers can provide conclusion for students. For example, the teachers can clearly point out whether or how the enterprise gets itself to the international market. Meanwhile, the teachers can provide analysis but not make conclusions. Instead, the teachers can guide students to utilize the analysis results to make conclusions in the discussion of the case or in the classroom. The teachingoriented cases only provide facts or phenomena, and the discussion focuses on the topic of decision. For example, students can discuss such issues as whether to acquire an enterprise, whether to get it to the international market or 
whether to adopt a human resource management practice. The teacher should not provide relevant theories of management or the analysis in the text; instead the teachers should assign it to students and guide them to carry on discussion in the classroom. Through comparison, the two case teaching methods have the similarity that is both are required to clearly state the problems to be solved and all the related background information of the company in the case and the related industry; while the difference of the two cases teaching methods is the writing of theoretical cases. The individual cases should directly cite one or several concepts, theories or models in the management fields to perform analysis, and the theoretical analysis can be scattered in the case and also can be integrally presented after the content of the case.

\section{The Case Teaching of logistics marketing under the Applied Transformation}

With the constant development of domestic logistics, more and more attentions have been paid to the teaching quality of marketing. However, as to many students majoring in logistics management who just start out for learning, they have less social experience and deficient cognition of management life phenomena and practices. The case teaching can effectively help students to understand the basic concepts and theories of logistics marketing, cultivate the abilities of students to apply the principles of logistics marketing in analysis of practical logistics problems, improve the interest of students in learning and achieve good teaching performance. When making the classroom case teaching of logistics marketing under the applied transformation linked with the practices, we should focus on the teaching quality of logistics marketing in the discussion of issues, including the scope of case teaching, the objective of case teaching, the implementation process and links and the content of cases.

The scope of case teaching of logistics marketing under applied transformation includes these majors that study on theories, operation rules and management of all fields relevant to logistics marketing activities, closely combine theory with practice, has strong applicability and can directly serve the logistics construction.

The objective of case teaching of logistics marketing under applied transformation is to cultivate the abilities of students to apply theoretical knowledge to analyze and solve practical logistics problems. The application of case teaching method in the course of logistics marketing is conducive to arousing the learning enthusiasm of students, deepening students' comprehension and grasp of theoretical knowledge of logistics marketing and improving the teaching performance. Therefore, the case teaching method is a good method that can cultivate the abilities of students to link the theory with the practice.

Besides delivering the problems or biographies of enterprises, the case for case teaching method should highlight the sensitivity of case users for the enterprise environment, enrich the possibility of theoretical application, list the decision analysis related to the company management, the supply of marketing talents, the scale of capital market, the possibility of financing, the supply of labor, the economic and trade rewards provided by the government, the roles of enterprise products in the life of ordinary people and so on. At present, experts and scholars still have different views and opinions on the industrial cases, and with the rapid growth of demands for case teaching, it urgently needs more exploration and improvement.

\section{EXAMPLES OF CASE TEACHING}

The case teaching can be divided into three parts, including teaching plan, case text and teaching guide, which are respectively stated below:

\section{A. Teaching Plan}

1) The necessary tools for the case teaching: The necessary tools for case teaching include the text of cases, syllabus, teaching plan, blackboard-writing plan, audio and video tape, projector, game, narration, question grouping and reading. Three roles for the case teaching are presiding teacher, students and the case teaching teacher. The whole teaching process includes the pre-semester preparation of presiding teacher and students, tasks of each class teaching . The teaching methods of case teaching teachers, which are respectively stated below:

2) The pre-class preparation of case teaching: (1). The teacher should E-mail the electronic documents of seating chart, basic data sheet of students, campus map, classroom map and drawing of site to the organizer within two weeks before giving lessons. (2). the teacher should remind students of reading the content of case and prepare the pre-class homework within one week before giving a lesson on each case. (3). as to films of certain cases, the teacher needs to remind students of watching the pre-class films.

3) The presiding teacher: The presiding teacher should make preparation for properly integrating the case into the course before the semester, pay attention to the correlation between the cases and the course and divide the course students into groups in accordance with the diversified principles with 8 students per group. In each case teaching class, before class, the presiding teacher should first understand the content of the case; in the lesson, the teacher should guide students to carry on group discussion. During the case discussion, the teacher should score it in accordance with performance of students; after the case discussion, the teacher should review the performance of students in this time, ask students to raise questions, explain the key reading points of the next case and make pre-reading data clear; after the class, the teacher should give out the classroom performance result and the score of schoolwork at this time.

4) Students: Before the semester, students should read the course outline, organize the learning research group and know about their background. The task of students in each lesson includes: (1) Before class: read up the case and supplementary teaching materials, put forward opinions, 
reasons and analytical methods for the discussion outline of case, write at least one A4 page of report, put out the report in the way of typewriting, hand in the report to the presiding teacher on the same day of lesson and participate in the group discussion; (2) In class: students should strive to make a speech, participate in discussion, and record the content on the blackboard; (3) After class: students should organize the case notes, deduce the logic of case, and write comments on each issue discussed in the case.

5) The teacher of case teaching: The teacher of case teaching should appear in the classroom within 10 minutes before class, to welcome the arrival of all students. In class, the teacher should expressly write the number of minutes for each stage on the blackboard, and then guide students to make case discussion (raise question - listen - answer) according to the schedule. The teacher can ask specific questions to the students having specific background, write the questions on the proper places of different blackboards according to the logic order of this setting, suitably further discuss the opinion-reason-analysis, remember the speech of every student, and repeat the logic of the content recorded on the blackboard before the class is over. After class, the teacher should score the student who make speeches in the classroom after going to the office, respectively give students a letter and inform them of the score and the reason of score acquired.

6) Teaching plan: Teaching plan is also called classattending script. The teacher of case teaching should do the following things: read the case and teaching notes to establish 1 2 main learning objectives; analyze the case to find out how to combine case practice with the theories; make sure of the discussion themes and set a certain time to discuss each topic; determine the discussion process and the time order of implementation; predict difficulties that students will encounter and guiding methods; design opening questions; design the context exchange between the case discussion and the theoretical discussion; estimate each time period; design the questions of field transition between time periods; prepare auxiliary teaching materials; design the use mode of the blackboard; find the students that you want to ask (generally, only 20 30 students will be asked); design the way of conclusion. It is suggested that teaching time should be 120 minutes and adjustment can be made in accordance with the level of students and the actual teaching situation. Make the discussion topic list and the schedule. The schedule of teaching is presented in the "Table I" below.

TABLE I. THE SCHEDULE OF TEACHING

\begin{tabular}{llll}
\hline \multicolumn{1}{c}{ Items } & $\begin{array}{c}\text { Time } \\
\text { (Minutes) }\end{array}$ & $\begin{array}{c}\text { Cumulative Time } \\
\text { (Minutes) }\end{array}$ & \multicolumn{1}{c}{ Principal } \\
\hline Introduction & 5 & 5 & Presiding teacher \\
Group discussion & 30 & 35 & Presiding teacher \\
Rest & 5 & 40 & Presiding teacher \\
Case discussion & 80 & 120 & Teacher of case \\
Rest & 20 & 140 & Presiding teacher \\
\hline
\end{tabular}

\section{B. Case Text}

For the content of case text, there is no given standard, but it's suggested that all cases can include the following content:

1) Introduction of the case: Concisely introduce the role and background of decision-makers, and the problems faced with (that is the problems that should be solved, namely, also the main issue in discussion of cases).

2) Explanation of the environment and complete background of the case institution: For the environment, it may include competition, market or other main environment (such as politics and law, economics, society and technology) related to the issue for discussion; for the introduction of overall environment, if related to the issue for discussion in the case, it must be explicitly explained.

3) Description of the case: It's suggested that relatively elaborate illustration should be provided, because it's the background of decisions. In most cases, the development course of case company must be provided so as to make readers feel alike on the scene and deeply experience the situation of decision-makers, while the decisions and policy information related to the issue for discussion must be presented in the case at a great length.

4) Issue related to the discussion issue and decision points (Not absolutely necessary): The information related to the case discussion but not included in the abovementioned scope can be included according to the need of case writing.

A good case should meet the need of the course, providing an obvious focus and enough information to make a meaningful quantitative analysis in the process of decisionmaking, which should be well organized but not preanalyzed so that the company has enough information to know the external environment and external dynamic condition when making decisions. Moreover, the good case should have the financial connotations and have two or more alterable feasible programs to generate the discussion in class. In addition, the case needs to be finished within 80 minutes and it is better for to tell students the beginning and the end of the event (major events).

\section{Teaching Note}

The teaching note should be limited to ten pages. The main objective of teaching note is to assist the case teaching. Therefore, the teaching note must clearly indicate the theme, applicable field courses, applicable learning object, related discussion issues, analysis tools and methods that may be used, and possible solutions of the case. Therefore, the teaching note must include the following elements:

1) Abstract of the case content: Simply introduce the content of case, which is limited to three hundred words.

2) Teaching objective: Explain the type and applicable courses and objects of the case and predict the case teaching can help students to cultivate certain ability and reach a certain learning effect. 
3) Discussion issues and detailed annotation: This part is the key point of teaching note, so it's necessary to put forward detailed discussion issues, and provide possible solutions for these issues so that teachers can guide students to speculate problems and have a discussion and conduct an analysis and provide solutions for these problems in the process of teaching.

\section{4) Other points worth discussing or summarizing}

5) Appendix: The appendix can include supplementary materials and analysis materials related to case such as reference websites, media reports, financial statement, related reports and so on, which can help teachers and students to further understand the related people, thing and object mentioned in the case and provide relevant information needed when discussing issues.

\section{CONCLUSION}

Under the applied transformation, the significance of the case teaching methods of logistics marketing lies in changing the traditional teacher-dominated and students-supplemented teaching methods into a participant (student)-centered learning style, which deliver industrial problems and solutions or case biography in teaching and study, enhance the study interest of students, stimulate the students' thirst for knowledge so as to cultivate students' knowledge, skills and attitude. This article respectively discusses three parts of the case teaching of logistics marketing under the applied transformation: teaching plan, case text, and teaching note, the whole implementation process and temporal planning of the case teaching and so on. However, in the case teaching, the design of the teaching materials of the practice course should be noticed. In addition, there exists a certain gap between cases and theories; the practical teaching abilities of teachers, the participation of students and other problems should be pre-considered. Only through this way can the case teaching play the good performance.

\section{ACKNOWLEGEMENT}

It should express the deepest gratitude to Fujian Providence Social Science with serial number FJ2016A14 and name of "Study on coupling and symbiosis of professional groups and regional industrial groups under the transformation from undergraduate universities to applied type".

\section{REFERENCES}

[1] Qian Jing, 2012, "Application of the Case Teaching Method in Teaching of Macroeconomics and Microeconomics", Journal of Henan Finance \& Taxation College, Issue 2.

[2] Zhang Jie, 2011, "Study on the Case Teaching Research of Western Economics ---Take Independent Colleges for Example" [J], China Education Innovation Herald, Issue 19.

[3] Zhao Jing, 2012, "Approaches for Improving the Effectiveness of Basic Course Teaching of Economics in Higher Vocational Colleges." [J], China Management Informationization, Issue 11.

[4] Liu Jie, Chen Haibo, 2008, "Statistic Analysis of Results and Teaching Reform Countermeasure Research of Macroeconomics" [J], Success (Education), Issue 05.
[5] Jia Yinshi "Discussion on Approach of Improving the Teaching Effect of Law Major \& Western Economics" [J], Consume Guide, 2008, Issue 20 .

[6] Liang Zhenying, 2009, "Some Experience on Teaching of the "Introduction to Economics" [J], China Education Innovation Herald, Issue 10 .

[7] Hu Chaoju, Gao Xue, Hu Chaobing, 2011 "Reflection on the Course Teaching Reform Path of the Tourism Economics of Colleges and Universities" [J], Economic Research Guide, Issue 35.

[8] Liu Yinghua, Wan Lei, 2012, "Exploration and Analysis of the Course Teaching Reform of the Tourism Economics of Higher Vocational Colleges and Universities" [J], Continue Education Research, Issue 09.

[9] Li Ting, 2009, "Case Teaching Mode of Harvard University and Corresponding Enlightenment of" [J], Consume Guide, Issue 24.

[10] Fang Huilong et al., 2010, "Application of Reverse Case Method in the Basic Medicine Teaching of Adult Education Undergraduate" [J], Chinese Journal of Social Medicine, Issue 03.

[11] Bao Ang, 2011, "Application of the Case Teaching Method in the Undergraduate Teaching of the Business Administration Major" [J], Journal of Changchun University of Science and Technology, Issue 06. 